\title{
INCLUSIVE EDUCATION: PREPARATION OF TEACHERS, CHALLENGES IN CLASSROOM AND FUTURE PROSPECTS
}

\author{
Malik Ghulam Behlol*
}

\begin{abstract}
The focus of this study was to examine the preparation of teachers, challenges in classroom and future prospects of inclusive education system in Pakistan. The major research questions of the study were: What is the attitude of teachers working in inclusive schools towards inclusive education? What is the preparation level of teachers working in the inclusive schools? What are the challenges faced by the teachers in these schools along with the future prospects of inclusive education system in Pakistan. It was a descriptive study and the researcher used semi-structured interview and accessibility checklist to collect qualitative and quantitative data to answer the research questions. The validated instruments were administered to six principals and twelve teachers working in inclusive schools. The study revealed that the teachers working in the inclusive education schools have not got proper training to work with the students having special needs. Moreover the accessibility of school infrastructure does not address the needs of all student. Curriculum, equipments, teaching learning aids and assessment methods also need to be readjusted. Principals and teachers have mixed opinions (positive as well as negative) about the success of inclusive education system in mainstream schools. They suggested that government may invest more financial and technical resources to train teachers and provide technological equipments if they want to integrate students with special into regular classrooms.
\end{abstract}

Key words: Inclusive education, Teachers, Classroom Challenges, future prospects

*Assistant Professor, Department of Education, Fatima Jinnah Women University, Rawalpindi. 


\section{Introduction}

Inclusion is the process of modifying the formal educational institutions in such a way that they may address and respond to the diverse needs of all children through increasing participation in learning and reducing exclusion from the main stream education. The exclusion of the students with special needs from the main stream institutions may aggravate their disability and negatively effects their development. Bartolo, (2010) reported that only 2\% children with special needs attend schools while one third of the total are out of schools. According to Tahir \& Khan (2010), about 20 percent of the world's poorest people are those who suffer from some sort of disability. Over 90 percent of children with disabilities in developing countries do not attend school. The literacy rate of adults with disabilities is as low as three percent - and, in some countries, as low as one percent among women with disabilities. All the above facts make it clear that the dream of 'Education for All (EFA)' cannot come true unless all the children including the ones with disabilities and other vulnerabilities have access to the mainstream education. Inclusive education is the only way to ensure that all children, including the children with special needs may attend schools. The state may realize its responsibilities to provide free educational opportunities to all children irrespective of cast, creed, race or religion. Article 28 of the United Nation Convention on Rights of Children (UNCRC, 1989) states that compulsory primary education and accessibility of educational \& vocational information and guidance to all children. Article 23 binds the states to ensure that all children with disabilities are enjoying full and decent life. It also states that all the children may have access to, and opportunities to complete, free and compulsory primary education of good quality. The report of the World Conference on Education for All (1990) in Jomtien, Thailand reveals that many students at primary level are out of schools due to different factors such as poverty, incompetent teachers, lack of facilities and non-provision of educational opportunities. The United Nations Convention on Rights of Persons with Disabilities (UNCRPD) reports the importance of mainstreaming of persons with disabilities as an integral part of relevant strategies for sustainable development (UNCRPD, 2008).

Children with special needs are divided into certain groups such as street children, rural female children, marginalized children, vulnerable children, working children and children with difficult circumstances. They are by and large excluded from mainstream education and development that may have serious repercussion for the national integrity and solidarity of the country (Government of Pakistan, 2005). The current National Education Policy 2009 has laid great stress on bringing these children in the mainstream education system that may promote social, national cohesion. Increased social exclusion expresses itself in different forms like ethnic strife, sectarianism and extremism etc. (Government of Pakistan, 2009). Inclusive Education approach has been implemented in 12 primary and secondary schools located in the ambit of the Federal Directorate of Education (FDE) in collaboration with the International NonGovernmental Organizations. The study was designed to get the answer of the following research questions: what is the preparation level of teachers working in the inclusive schools? (1)What is the attitude of teachers towards inclusive education working in inclusive schools? (2) What are the challenges faced by teachers in these schools along with the future prospects of inclusive education in Pakistan (3) What is the preparational level of teachers working in the inclusive schools? It is anticipated that this study may contribute to formulate effective strategy for the implementation of the inclusive education system in Pakistan with respect to preparation and 
training of the teachers to work in these institutions. It may also support to achieve the target of universal primary education set in the national education policies and international declarations to educate all the age group including the children with disabilities.

\section{Review of Literature}

Inclusive education is a process of bringing support services to the child, rather than moving the child to the services. Norwich and Nash (2011) argued that in USA and Europe the interventions of inclusive education were started as a part of special Education for the students with disabilities in 1980s. Researchers and educationists made efforts in Europe and USA to include the students with disabilities in mainstream schools that have reflected better results. Millions of children in South Asia are out of schools and majority of them are the students with disabilities. The reasons of this exclusion are the inaccessibility or irresponsibility of the regular education system to accommodate them in schools. Studies conducted by Lilian \& Sandy (2010) found that inclusive education is needed to accommodate children with diverse educational needs from all segments of the society. They endorsed that the regular education system needs changes to accommodate the individuals with special needs. Roger \& Julie (2001); Khan, Ahmed, and Ghaznavi (2012) concluded that inclusive education is not concerned only with the students with disabilities but it also talks about all those who are under privileged and don't have access to the educational facilities on equal basis.

According to Brownell, Ross, Colon and McCallum (2005), inclusive education is a gradual process and goes beyond the inclusion of the students with disabilities into the regular school environment. It focuses on the wider scope for educational reforms and policies to respond to the needs of different ethnic, religious, cultural and social groups as well as to reinforce the uniqueness and individuality of each child. It may be less expensive, as it contributes to check the drop-out rates and may have a positive impact on the achievement of higher learning outcomes. According to Ajuwon (2008), children may get better opportunities of learning social skills and collaborative learning approaches in an inclusive environment. Kuyini \& Desai (2007) concluded that successful inclusive practices in regular classrooms enhance the positive attitude of the teachers towards the students with disabilities. It is an important aim of education to teach the students how to live together in a democratic society. It may promote integration, harmony, collaboration in the files and the ranks of the society. It may overcome the gaps between the haves and have nots: main stream students and special needs students, brighter and mediocre students for the harmonious development of the society as well as the learning process. It may strengthen our belief that human beings possess individuality but they may live, learn and work together. This will form the world to a just, non- discriminatory and inclusive society for all. It seeks to eradicate different forms of exclusion, such as, the social gaps, marginalization, lack of educational opportunities and poor learning outcomes among migrant populations. Interaction between students with and without disabilities promotes friendships, harmony, goodwill and national integration (Zenija, 2011).

According to Emam, Mohamed \& Mohamad (2011), the teachers need in-service and pre-service training to meet the challenges of inclusive education. It is an accepted fact that practice makes a man perfect, and we learn by doing the things again and again through conscious efforts. The nature of the problems of the students with special needs is different as 
compared to the problems of the students in the mainstream schools. They have limitations to react to the situation a little bit late as compared to the normal students. The teachers need greater patience to respond them and may also need to change the delivery pace for the students. Pre-service teacher education programme may ensure adequate scope in the curriculum on the inclusive education approach. The continuing professional development is essential to meet the challenges in inclusive education. This reflects that before introducing inclusive education, the teachers should be appropriately trained and motivated. School based mentoring through teacher collaboration, learning and self-reflection may make the inclusion of students with disabilities easier because it enhances the learning, knowledge, skills, wisdom and insight of the teacher in an untraditional way (Norwich and Nash, 2011; Zenija , 2011).

According to Bartolo (2010), head teachers think that the success of the inclusive education depends not only on the training of teachers but also required holistic changes in the overall environment of the school. It may include trained teachers, trained support staff, accessible infrastructures and accessible teaching /learning aids, curriculum adjustment, and modified assessment practices. According to Lilian \& Sandy (2010), there are certain barriers which halt the movement of inclusive education. These barriers include higher level of socioeconomic diversity, discriminatory negative attitude, inflexible curriculum, communication problems, inaccessible and unsafe environment, inadequate support services, lack of parental involvement and trained human resources. Klingner, et al., (1998) concluded that inclusive education is expensive because it needs full time support and one-on-one instruction from highly trained special education teachers to make it a success. According to Yasmeen, Minto \& Khan (2010), at an operational level, inadequate infrastructure, limited learning materials and teaching skills coupled with insufficient clinical service support leads to the exclusion of students with disabilities from the mainstream system. Moreover poverty, disability, conflict and a lack of supporting policy frameworks are also some of the key contributing factors to exclusion.

Government of Pakistan has ratified UNCRC and UNCRPD that require that the students with disabilities get enrolled in mainstream education system without any discrimination. Government of Pakistan is also a signatory of MDGs and EFA declarations that urge to address the educational needs of students with disabilities and other marginalized children. National Education Policy of Pakistan (2009) endorses the social inclusion and child friendly inclusive education. It has also recognized the social role of education and recommends that education is not only about the individual; it has a societal role of selecting, classifying, distributing, transmitting and evaluating the educational knowledge, reflecting both the distribution of power and the principle of social contract. If immediate attention is not paid to reducing social exclusion and moving towards inclusive development in Pakistan, the country may face unprecedented social upheavals (Govt. of Pakistan, 2009). Inclusive education is a new concept therefore only a few schools are striving to create an inclusive environment through experimentation with various approaches.

Takala, Pirttimaa and Törmänen (2009) conducted a study on the topic 'Inclusive special education: the role of special education teachers in Finland'. The major focus of the study was on the concentration of the work of 133 special education teachers in mainstream education in Finland. It was a descriptive study and the questionnaire was used to collect the data. The work of the special education teachers was revealed to consist of three elements: teaching, consulting 
and background work. Teaching, often focusing on giving support to children who had challenges in the main academic subjects, was realized in small groups, in co-operative or individual settings. Consultation mainly concerned co-operation and discussion. Behavioural challenges needed a targeted approach. The main problems experienced by the teachers were the lack of time for consultation and co-operation, an unclear work specifications and too much burden. The work of special education teachers was partly inclusive, but also entailed segregate elements.

Ahmmed, Sharma and Deppeler (2012) conducted a study on the "variables affecting teachers' attitudes towards inclusive education in Bangladesh". The major focus of the study was to examine variables influencing teachers' attitudes towards inclusion of students with disabilities in regular classrooms at primary level. A total number of 738 teachers working in 293 government primary schools were selected for data collection. The results reflected that perceived school support for inclusive teaching practices and a range of demographic variables including previous success of teaching students with disabilities and contact with a student with a disability were associated with more positive attitudes of the teachers towards the inclusive education. The results revealed implications for educators, policy-makers and international organizations working on the implementation of inclusive education.

\section{Methodology of the Study}

The focus of this study was to explore the preparation of teachers, attitude of teachers and challenges for the teachers to work in inclusive education system in Pakistan. It is descriptive study because the variables of the study were examined in natural settings. The researcher has applied quantitative and qualitative approaches to collect the data. Quantitative approach was considered useful to collect detailed data about the tangible (doors stairs, entrance and seating) aspects of the study whereas the qualitative approach was applied to collect data about intangible (attitude of teachers) aspects of the study.

\section{Population, Sample and Participants}

The population of the study was 12 primary and secondary schools in the ambit of Federal Directorate of Education, Islamabad where the inclusive education approach was practiced. The schools are located in different sectors of the urban area of Islamabad that is the capital city of Pakistan and there were 196 students with disabilities in these schools. Federal Directorate of Education is the administrative organization to manage and supervise the schools in the capital city. The target populations for this study were students with disabilities, teachers and the Principals of the schools. There were twelve principals and 24 trained teachers. Six principals and twelve teachers were randomly selected as the sample of the study. Three principals of sample group were appointed through Federal Public Service Commission and three of them were promoted through service promotion. The range of experience of the directly appointed principals was 5 to 8 years whereas the range of the experience of the promotees was 15 to 25 years in the education department. The teachers were selected applying multistage random sampling technique. The experience of the teachers in the sample group has varying 
duration. The minimum experience was 5 years and the maximum duration of experience was 20 years.

\section{Instrument of the Study}

The semi-structured interview was constructed to collect the data of the study. It was administered to the respondents by the researcher himself. It was pilot tested for validation before administration. There were fourteen interview questions to find out the preparation level of teachers, their attitude to inclusive education, challenges that they are facing in inclusive classrooms. A check list was constructed after consultation with the expert of accessibility involved in Special Talent Exchange Program (STEP) to assess the accessibility of the school infrastructure for students with disabilities.

\section{Data collection and analysis}

The researcher visited Federal Directorate of Education and obtained permission for the collection of data. A meeting with the focal persons of inclusive education was arranged to develop a schedule of school visits and to ensure availability of the principals and teachers in the school. The researcher himself conducted interview of the principals, and their responses were recorded with the help of audio recorder. The emerging themes were categorized and critically analysed.

\section{Research Ethics}

The researcher obtained permission from the parents of students with special needs to conduct this study. The instrument of the study does not contain any sensitive items that injure the self respect of disable students. The respondents were ensured about the secrecy of the data. Copy of the research report was mailed to the participants (teachers and heads of institutions) so that they may focus on the findings of the study. Data collected through interview was analyzed applying thematic approach. The emerging themes were categorized under different themes. They were analyzed by comparing and contrasting them on the basis of different conceptual ideas. Simple percentage was applied to analyse the quantitative data gathered from checklist.

\section{RESULTS}

\section{Qualitative Analyses of Interview Questions}

A semi-structured interview was conducted in which the questions were asked for response from six principals and twelve teachers working in inclusive schools. It explains the viewpoint of respondents about level of preparedness of teachers, their attitude and the challenges that are faced by them in inclusive education system.

\section{Question 1. What is the attitude of teachers towards inclusive education?}

Responses gathered from the teachers and principals with the interview revealed mixed opinions about the inclusive education. The teachers who had less than 10 years of teaching experience were critical about inclusive education because they viewed that the mainstream 
students were penalized when taught with the students with special needs, due to the slow delivery of the lesson. The teachers have to address the educational needs of special needs students and adjust his/her pace and flow of words and ideas. There were frequent discipline problems that challenged the patience of the teachers and the teaching learning process in the classroom. On the other hand, the teachers who had more than 10 years of experience reflected that the inclusive education system may be a success with some certain conditions. They viewed that the teachers have to do some extra efforts to solve the learning difficulties of the students with special needs. They had the opinions that inclusive education may provide an opportunity to the marginalized group to integrate with the mainstream society and play their productive role for its development. They also viewed that it may check the dropout rate of the students with special needs. They reflected that the training is urgently needed to inculcate positive attitude in the mind and hearts of less experienced teachers. They may be guided how to address the problems of the students with learning difficulties in mainstream classrooms. It was also noted that the larger class size negatively affects the attitude of teachers towards inclusive education.

\section{Question 2. What are the challenges for the teachers in inclusive education system?}

The major challenges for the teachers in inclusive schools were discipline related issues such as hooting and stigmatization from the peers, non-availability of transport, critical learning difficulties, inaccessible school building, curriculum adaptations and adjustment in assessment practices. The changes in the attitude of teachers may occur changing and adjusting the entire system of school. Inclusive education approach may need to be compatible with the factors that may influence learning of the students in the school. It needs full involvement of the parents to support teachers for the education of special needs students. It also needs funding to modify the infrastructure of the school for adjusting it according to the needs the special students. Approaching curriculum on the basis of psychological basis also exclude the students with disabilities. School is a social institution to bring harmony, equality and goodwill in the society whereas psychological approach focuses on deviant, abnormal children to create a different environment as compared to normal children.

\section{Question 3. What is the nature and quality of training to work with students with special needs?}

The opinions of the teachers and principals about the nature and quality of in-service training to work in inclusive system indicates that there was no long term training session organized to update the knowledge and skills of the teachers to work in inclusive schools. Short term workshops for a week to train the teachers in these schools were organized. It is viewed by the teachers that the duration of the training session is not enough to bring changes in their attitude and equip them with the skills to work in these schools. They viewed that their experience in the education system has been contributing a lot to work with special needs students instead of the training imparted to them to launch inclusive education program.

The teachers and principals also criticized the content of the training session organized for one week. They viewed that the facilitators focused on details of different types of disabilities 
such as mentally retarded students, slow learner, hearing impaired, emotionally destabilized etc. But how to work with the children suffering from disabilities was never properly discussed.

\section{Question 4. What are the adjustments needed in the schools infrastructure for inclusive education?}

The principals viewed that they needed financial support from the department to adjust school infrastructure for the education of the students with special needs. They emphasized that these adjustments may be the prerequisite for launching inclusive education program. Inclusive schools need ramps, equipments (audio-visual aids, CCTVs, LVDs), development of resource room, sensitization of communities and parents.

\section{Analyses on Accessibility Checklist}

An accessibility checklist was applied to assess the infrastructural accessibility in inclusive schools.

Table 1

Analysis of the responses of teachers and principals about physical accessibility in inclusive schools

\begin{tabular}{|c|c|c|c|c|c|c|c|}
\hline 官 & Check List & 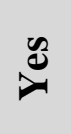 & Z & 证 & 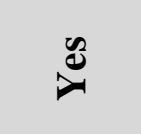 & $\stackrel{\circ}{Z}$ & 을 总 \\
\hline 1 & Accessible main entrance & 10 & 6 & 2 & $55.5 \%$ & $33.3 \%$ & $11.1 \%$ \\
\hline 2 & Accessible doors & 8 & 6 & 4 & $44.4 \%$ & $33.3 \%$ & $22.2 \%$ \\
\hline 3 & Ramps for wheel chairs & 4 & 14 & - & $22.2 \%$ & $77.8 \%$ & --- \\
\hline 4 & Accessible washrooms & 8 & 8 & 2 & $44.4 \%$ & $44.4 \%$ & $11.1 \%$ \\
\hline 5 & Accessible drinking water facility & 10 & 4 & 4 & $55.5 \%$ & $22.2 \%$ & $22.2 \%$ \\
\hline 6 & Accessible play ground & 2 & 14 & 2 & $11.1 \%$ & $77.8 \%$ & $11.1 \%$ \\
\hline 7 & $\begin{array}{l}\text { Accessible library, Computer Labs, tuck } \\
\text { shop }\end{array}$ & 2 & 10 & 6 & $11.1 \%$ & $55.5 \%$ & $33.3 \%$ \\
\hline 8 & $\begin{array}{l}\text { Accessible Examination and assessment } \\
\text { method }\end{array}$ & 02 & 10 & 6 & $11.1 \%$ & $55.5 \%$ & $33.3 \%$ \\
\hline 9 & Accessible learning materials & 6 & 4 & 8 & $33.3 \%$ & $22.2 \%$ & $44.4 \%$ \\
\hline 10 & Accessible teaching methodologies & 6 & 8 & 2 & $33.3 \%$ & $44.4 \%$ & $11.1 \%$ \\
\hline
\end{tabular}

Table No 1 reflects the viewpoint of teachers and principals about the physical accessibility in inclusive schools. The sample group viewed that 55.5\% of the schools have accessible entrance, $33.3 \%$ schools did not possess accessible entrance and $11.1 \%$ schools have entrance to some extent accessible for the students with special needs. About the classroom doors, $44.4 \%$ responded that they were accessible, $33.3 \%$ responded that they were not accessible and 22.2 responded that they are accessible to some extent for the students with special needs. $22.2 \%$ schools have ramps for wheel chair users and $77.7 \%$ did not possess ramps for wheel chair users. The sample group responded about the appropriate washrooms for 
the students with special needs in this order: $44.4 \%$ responded that appropriate washrooms were available in their schools whereas 44.4 responded that appropriate washrooms were not available in their schools. It was viewed by $11.1 \%$ respondents that the washrooms were user friendly for the students of special needs to some extent. $55.5 \%$ students responded that their schools possess accessible drinking water facility for the students with special needs whereas $22.2 \%$ responded that their schools did not possess accessible water facilities for the students with special needs. $77.7 \%$ respondents viewed that their schools did not have students with special needs friendly playground whereas only $11.1 \%$ students responded that their schools have a playground where they were able to participate in different games. $11.1 \%$ schools had accessible computer laboratories, library and tuck shop whereas $55.5 \%$ did not have special needs friendly library, computer lab. and tuck shop. 55 \% respondents viewed that the assessment practices do not care the needs of students with special needs whereas only $11.1 \%$ viewed that the examination practices care the interests and needs of the students with special needs. $33.3 \%$ students viewed that learning material and teaching methodologies are up to the requirements of the students with special needs whereas $33.3 \%$ respondents viewed that they do not address the requirements of the students with special needs.

\section{Discussion and Conclusion}

Attitude is the tendency of an individual indicating the level of his involvement and interest in certain tasks or things. It is preset of disposition that may positively or negatively affects the performance of the individual on the task. The results of the study reveal that the teachers working in inclusive schools have mixed opinions as far as their attitude towards inclusive education is concerned. The teachers with limited experiences are critical about the inclusive education. They reflected that the students with special learning needs are taught at the cost of the mainstream students and the teachers consume larger portion of their energies in concentrating on teaching to these students instead of running the learning activities in the classroom at a steady pace. The results of the study are consistent with the studies conducted by Mongwaketse \& Mukhopadhyay (2013), Jordan, Schwartz and McGhie-Richmond (2009), Rakap and Kaczmarek (2010), Cologon, (2011), Sharma, Moore and Sonawane, (2009), Masud, Sharma \& Deppeler (2012), Zenija (2011) in the past. Well balanced knowledge, skills and attitudes are three powerful components for successful implementation of inclusive education. Beacham and Rouse (2012) posits that positive attitudes are more likely to be sustained when teachers have the knowledge and skills to persist with inclusive pedagogies. However, the studies conducted by Sharma, Forlin and Loreman (2008) and Avissar, Reiter and Leyser (2003) are not consistent with the results of the study because they found that younger teachers had more positive attitudes than older ones. It can be done by making the inclusive education as part of school culture and over all environment of the school. It is also noted that larger class size negatively affects the attitude of teachers towards inclusive education because it demands greater work on the part of the teachers to address the problems of special needs students on individual basis.

The responsibilities of teacher include not only transferring of certain content, information to the students but also building of their character, vision, approach and ability to know that is not known, to solve the problem that presents threat to the entire fabric of the society etc. There are many challenges that the teacher faces in the classroom. The major 
challenges for the teachers in inclusive schools are discipline problems, hooting from the peers, non-availability of accessible infrastructure, critical learning difficulties, curriculum adaptations and adjustments in assessment practices. The nature and the quantity of the problems in inclusive classroom are far greater as compared to the mainstream schools. The teachers require proper training, increased rate of passionate commitment to work to solve the ever increasing problems in inclusive classrooms. The results of the study are also consistent with the studies conducted by Ainscow \& Cesar (2006) that also emphasize the need of longer and continuous training for the teachers to update their knowledge and skills to work in the classroom.

The results of the study reveal that without ensuring the infrastructural accessibility in the mainstream schools, it is not appropriate to launch inclusive education program. School environment must be in accordance with the needs of the special students. The classrooms, playground and drinking water facilities should be accessible to all students. Teaching methods, assessment practices and learning aids should also be as per the needs of the students with special needs. There is an urgent need of continuous long term teacher training and adjustment in the assessment practices, teaching methods and content material so that they may suit to their requirements.

\section{Recommendations of the Study}

Following are the recommendations of the study:

1. The study recommends that the teachers may be given continuous long term in-service teacher training to update their knowledge, skills and inculcate positive attitude to work in inclusive education system.

2. Needs of the special students may be considered at the planning phase of the construction of the school buildings and the policy makers may provide sufficient funding to furnish schools with necessary equipments to meet the requirements of the students with special needs.

3. Boards of Intermediate and Secondary Education (BISEs) in Pakistan may formulate policy to facilitate the students with special needs in the examination.

\section{REFERENCES}

Ajuwon, P. M. 2008. Inclusive education for students with disabilities in Nigeria: benefits, challenges and policy implications. International Journal of Special Education, 23(3), 11.

Avissar, G., Reiter, S. \& Leyser, Y. 2003. Principals 'views and practices regarding inclusion: the case of Israeli elementary school principals.'European Journal of Special Needs Education, 18 (3),pp. 355-69.

Bartolo, P. A. (2010). The process of teacher education for inclusion: The Maltese experience. Journal of Research in Special Educational Needs, 10(1), 139-148.

Brownell, M. T., Ross, D. D., Colon, E.P., McCallum, C. L. 2005. Critical features of special education in teachers preparation: A comparison with general teacher preparation. The Journal of Special Education, 38(4), 242-252.

Beacham, N., \& Rouse, M. ( 2012). Student teachers attitudes and beliefs about inclusion and inclusive practice. Journal of Research in Special Educational Needs, 12 (1), 3-11. 
Bender, W. N., Vail, C. O. \& Scott, K. (1995). Teachers' attitudes towards increased mainstreaming: implementing effective instruction for students with learning disabilities. Journal of Learning Disabilities, 28(2), 87-94, 120.

Cologon, K. (2011) 'Confidence in their own ability: postgraduate early childhood students examining their attitudes towards inclusive education.' International. European Journal of Special Needs Education, 23(2), 109-120.

Government of Pakistan, (2009). The National Education Policy 2009. Ministry of Education, Islamabad

Government of Pakistan, (2005). The State of Education in Pakistan. Policy and Planning Wing, Ministry of Education, Islamabad

Jordan, A., Schwartz, E. \& Mc Ghie-Richmond, D.(2009) 'Preparing teachers for inclusive classrooms. Teaching and Teacher Education, 25 (4), 535-42.

Klingner, J. K., Vaughn, S., Hughes, M.T., Schumm, J. S. and Elbaum, B. (1998). Outcomes for Students with and without Learning disabilities in inclusive classrooms. Learning Disabilities Research \& Practices, 13(3), 153-161.

Khan, I. K., Ahmed, L., and Ghaznavi, A. (2012). Child friendly inclusive education in Pakistan. Insight Plus, 5, 18-20.

Kuyini, A. B. and Desai, I. (2007). Principals' and teachers' attitudes and knowledge of inclusive education as predictors of effective teaching practices in Ghana. Journal of Research in Special Educational Needs, 7(2), 104-113.

Lilian, L. \& Sandy, L. (2010). South Africa: First step in the development of an inclusive education system. Cambridge Journal of Education, 31(3), 307-316.

Ahmmed, M., Sharma, U., \& Deppeler, J. (2012). Variables affecting teachers' attitudes towards inclusive education in Banglades. Journal of Research in Special Educational, 1 (4)

Mpho Otukile- Mongwaketse, M. \& Sourav Mukhopadhyay, S. (2013). Botswana PGDE student teachers' attitude towards inclusive education: implication for teacher tducation. Turkish Journal of Teacher Education, 2013, 2(1)

Mahmoud, M. Emam, M. M., \& Mohamed, A. H. H., (2011). Preschool and primary school teachers' attitudes towards inclusive education in Egypt: The role of experience and self efficacy. Procedia - Social and Behavioral Sciences 29 (2011) 976 - 985

Norwich, B. and Nash, T. (2011). Preparing teachers to teach children with special educational needs and disabilities. Journal of Research in Special Educational Needs, 11(1), 2-11.

Rakap, S. \& Kaczmarek, L. (2010) 'Teachers' attitudes towards inclusion in Turkey.'European Journal of Special Needs Education, 25 (1), pp. 59-75.

Roger, S., \& Julie, A. (2001). Excluding the included: A reconsideration of inclusive education. International Studies in Sociology of Education, 11(2), 177.

Sharma, U., Forlin, C. \& Loreman, T. (2008) 'Impact on training on pre-service teachers' attitudes and concerns about inclusive education and sentiments about persons with disabilities.’Disability \& Society, 23 (7), pp. 73-85.

Sharma, U., Moore, D. \& Sonawane, S. (2009) 'Attitudes and concerns of pre-service teachers regarding inclusion of students with disabilities into regular schools in Pune, India.'AsiaPacific Journal of Teacher Education, 37 (3), pp. 319-31. 
Tahir, R., \& Khan, N. (2010). Analytical study of school and teacher education curricula for students with special educational needs in Pakistan. Journal of Special Education, 11 (6)

Takala, M., Pirttimaa, R., \& Törmänen, M. (2009). Inclusive special education: the role of special education teachers in Finland. British Journal of Special Education 36(3) 2

UNICEF (2003). Examples of Inclusive Education in Pakistan. The United Nations Children's Fund (UNICEF), Regional Office for South Asia. http://unesco.org.pk/education/icfe/resources.

United Nation, UNCRPD, (2008). United Nation Convention on the Rights of Person with Disabilities. Washington, USA

UNESCO (1990). Education for All Global Monitoring Report. http://www.unesco.org/education/GMR/2007/Full_report.pdf.

United Nations (1989). United Convention on the Rights of Children. Washington, USA

Yasmeen, S., Minto, H., \& Khan, N. (2010). Policy and Practice in the educational inclusion of children and young people with visual impairment in Sri Lanka and Pakistan. The Educator, 22 (2), 17-22.

Zenija, B. (2011). School-based mentoring for professional development of inclusive school teachers. Journal of Teacher Education for Sustainability, 13(1) 72-83. 